OPEN ACCESS

Citation: Dilsha M.V., Satheesh G. (2021) Lectotypification of five names in the genus Blumea (Asteraceae). Webbia. Journal of Plant Taxonomy and Geography 76(2): 281-288. doi: 10.36253/jopt10530

Received: February 27, 2021

Accepted: March 25, 2021

Published: September 7, 2021

Copyright:@2021DilshaM.V., Satheesh $G$. This is an open access, peerreviewed article published by Firenze University Press (http://www.fupress. com/webbia) and distributed under the terms of the Creative Commons Attribution License, which permits unrestricted use, distribution, and reproduction in any medium, provided the original author and source are credited.

Data Availability Statement: All relevant data are within the paper and its Supporting Information files.

Competing Interests: The Author(s) declare(s) no conflict of interest.

Editor: Riccardo M. Baldini

\section{Lectotypification of five names in the genus Blumea (Asteraceae)}

\author{
Dilsha M.V., Satheesh G. \\ Centre for Post Graduate studies and Research in Botany, St. Joseph's College (Autono- \\ mous), Devagiri, Kozhikode-673008 \\ Corresponding authors. E-mail: dilshayuvraj@gmail.com, george.satheesh@gmail.com
}

\begin{abstract}
The lectotypification of five names in the genus Blumea (Asteracea): Blumea glomerata DC., B. pterodonta DC., B. hamiltonii DC., Blumea arenaria DC. and Blumea virens DC., is discussed and lectotypes designated.
\end{abstract}

Keywords: Asteraceae, Blumea, Nomenclature, Taxonomy

\section{INTRODUCTION}

The genus Blumea DC. (1833: 514) (Asteraceae) consists of about 100 species worldwide (Pornpongrungrueng et al., 2016). This genus is one of the largest in the tribe Inuleae and its highest diversity is seen in Tropical Asia (Anderberg, 1991). A total of 36 taxa are present in India (Hooker 1882; Hajra et al. 1995).

As part of the taxonomic studies of the genus Blumea, the authors studied relevant literature and critically examined specimens in different herbaria. During this we found that some names need typification. Hence we lectotypified five names viz, Blumea glomerata DC., B. pterodonta DC., B. hamiltonii DC., Blumea arenaria DC. and Blumea virens DC. according to article 9.3 of Schenzen code (Turland et al. 2018).

Blumea glomerata DC. in Wight (1834: 150)

Type: India, Negapatam (K barcode K000978451, digital image!) lectotype here designated; isolectotype (K barcode K000978450, digital image!), NY (barcode 02201069, digital image!), E (barcode E00417373, digital image!), P (barcode P00692160, P00692161), Figure 1.

This species was first described by De Candolle (1834:15) in Wight's Contribution of India. He cited the collection locality as "In arenosis maritimis circa Madras et Negapatam. Ad Montes Circars'. De Candolle's description was based on one collection of Wight (Herb. Wight propr. 1434) and specimens of 


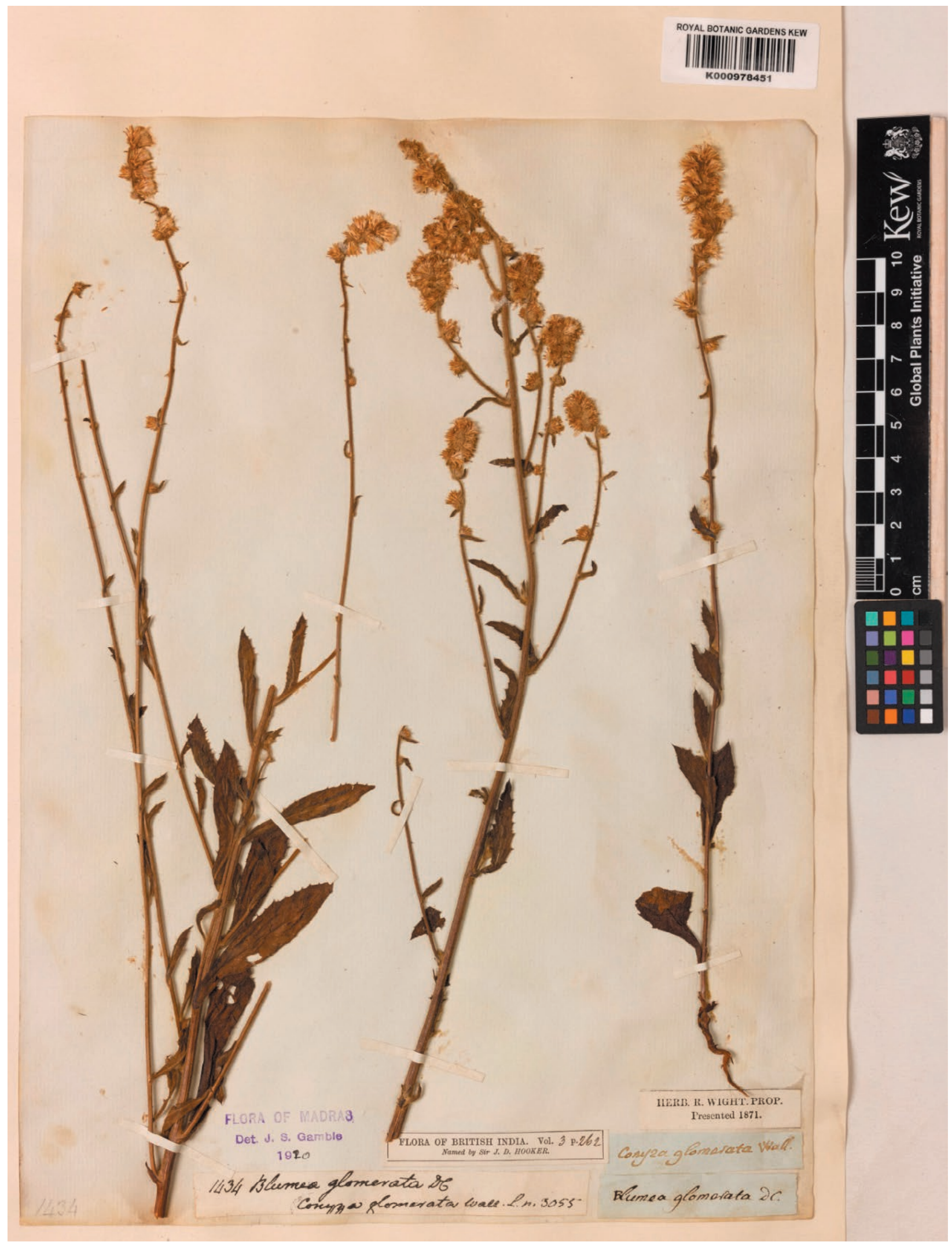

Figure 1. Lectotype of Blumea glomerata (K000978451). (c) Copyright of the Board of Trustees of the Royal Botanic Gardens, Kew. 
Heyne and Roxburgh; Wallich 3055 is also cited under the name Conyza glomerata, a nomen nudum based on specimens from Prome, Amherst \& Moalmyne and Nepalis. These all are syntypes according to article 9.6 of Shenzhen code. Pornpongrungrueng (2016) in her revision of the genus Blumea DC. in continental South East Asia cited a holotype at Kew (Wight 1434). She incorrectly cited the type locality as Myanmar, Prome and cited only one specimen. The use of the term holotype is not correct because three (or possibly six) syntypes were cited in the protologue. The term holotype is not correctable to lectotype because of the absence of a designating statement (Art.7.11). So Pornporngruengs citation cannot be counted as an effective lectotypification.

\section{Blumea pterodonta DC. in Wight (1834: 16)}

Type: India: Peninsula Indiae Orientalis, "Ad littora maris, locis arenosis magis in Coromandelia frequens", Herb. Wight propr. 1437 ( E barcode E00413688!, digital image!) lectotype here designated. Figure 2.

This species was first described by De Candolle (1834: 15) in Wight's Contribution of India. De Candolle used Herb. Wight propr. 1437 for describing this species. As a result of thorough searching in different herbaria we traced two sheets in $\mathrm{K}$ (barcodes K000974743!, K000974744!), one each at E (barcode E00413688!) and P (barcode P01816053!). According to Art.9.6 of Shenzhen code these are all syntypes. The sheet in E bears an annotation of De Candolle's Peninsula India Orientalis with a hand written annotation about the species and bears all characters and agrees well with the protologue. It qualifies to be designated as the lectotype of Blumea pterodonta.

\section{Blumea hamiltonii DC. (1836: 439)}

Type: lectotype, Step I. Randeria (1960: 249). Step II.: India (K barcode K000978436, digital image!) lectotype here designated; isolectotypes (K barcode K001118229, K001118230, K000974837, K001118231, K000978438, K000978439, K0009978440, digital images!). Figure 3.

This species was described by De Candolle (1836: 439). De Candolle used Wallich's specimens for describing this species. Randeria (1960) in revisionary studies mentioned its type material as 3938/48 of Wallich in Kew. The protologue reads "in India or. ad Kamaon, ad Sukonaghur, ad Koemari legit cl. Hamilton. Conyza necessaria Ham.! Herb. Gnaphalium Hamiltoni Wall.! cat. n. 3938 comp. n. 48". In Wallich's Numerical list (1829-1849), cat. n. 3938 is Stemodia gratioloides Benth. and cat. n. of Gnaphalium hamiltonii is 2938 . So, in protologue it must be a typographical error. There are four sheets of Wallich 2938 in Kew with different barcode numbers. But Randeria did not make a precise indication regarding which specimen could be treated as type and no particular notes is present in any of the sheets. In all the sheets atleast 4 specimens are mounted. Randeria's determinavit label is found in 2 sheets. So, Randeria's typification can be treated as effective first step lectotypification (Art. 7.11 of the ICN). Based on accurate state of preservation and accurate matching with the protologue, the specimen K000978436 is selected here as the lectotype. Other specimens belonging to the original material should be treated as isolectotypes.

\section{Blumea arenaria DC in Wight (1834: 13)}

Type: India "in arenosis proper Negapatam", Wight 1422 (K barcode K000978497, digital image!) lectotype here designated; isolectotype (K barcode K000978496, digital image!). Figure 4.

This species was described by De Candolle (1834: 13). Giri and Mitra (1984:143) created a new combination (Blumea obliqua (Linn.) Druce var arenaria (DC) Giri et B. Mitra) using this name. They also cited type material of Blumea arenaria as Wight 1421 (K). As Giri and Mitra (1984:143) did not do any lectotypification by citing the single specimen mentioned, their reference is not considered as lectotypification. Currently there are two specimens at Kew belonging to Wight 1421 with different barcode numbers (K000978496 and K000978497) and also we traced Wight 1421 sheets from E and G. An effective lectotypification is needed in order to narrow down Giri \& Mitra's to a single specimen (Art. 9.6 of the ICN). Hence, we select the sheet K000978497 as the lectotype of Blumea arenaria because it exactly matches with the protologue.

\section{Blumea virens DC. in Wight (1834: 14)}

Type: lectotype, Step I. Randeria (1960:272). Step II.: India, Negapatam (E, barcode E00417360, digital image!) lectotype here designated; isolectotype (E barcode E00417361, digital image!). Figure 5.

This species was described by De Candolle (1834: 14). Randeria (1960) in revisionary studies of the genus 


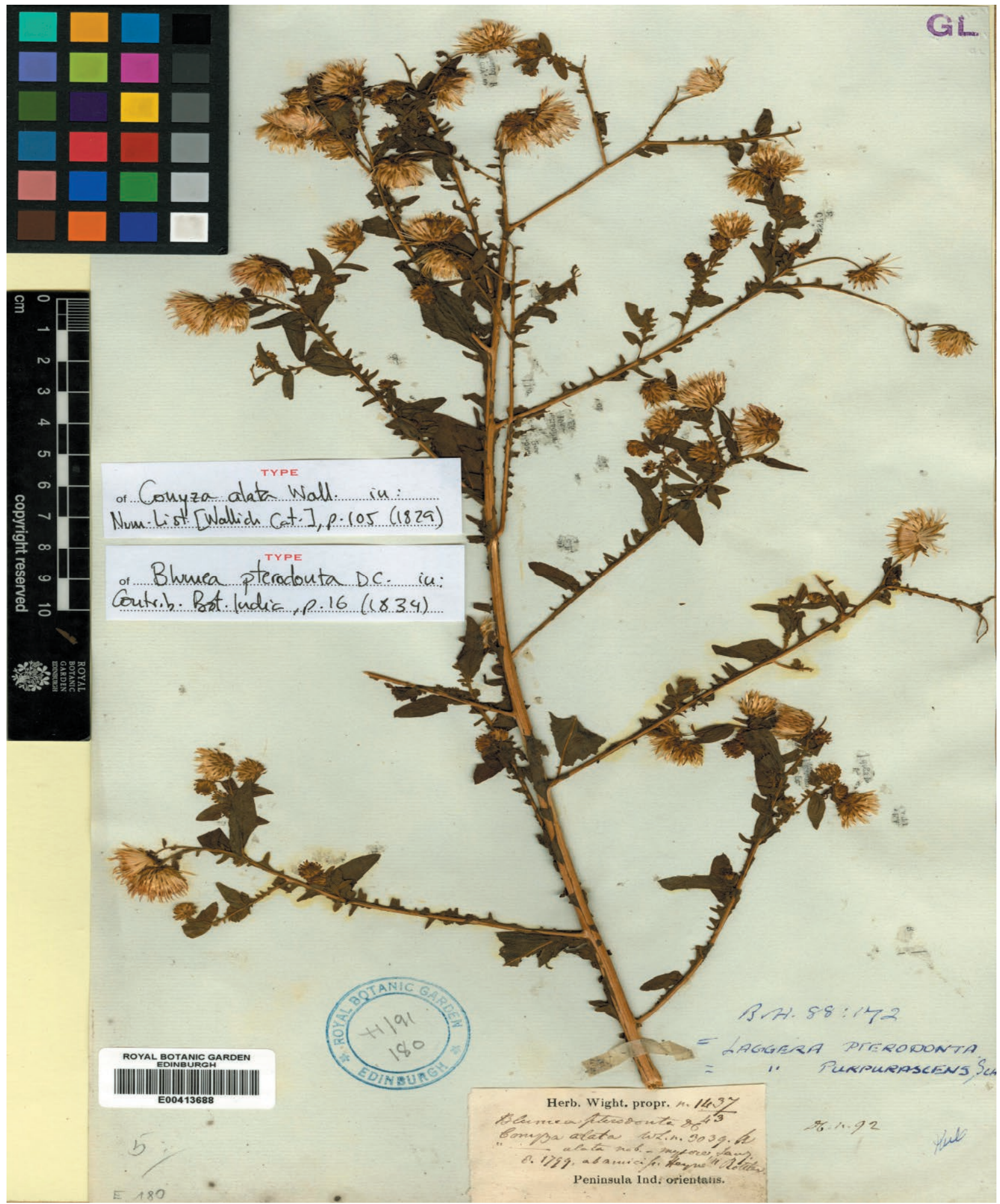

Figure 2. Lectotype of Blumea pterodonta (E00413688). ( Copyright of the Board of Trustees of the Royal Botanic Gardens, Kew. 


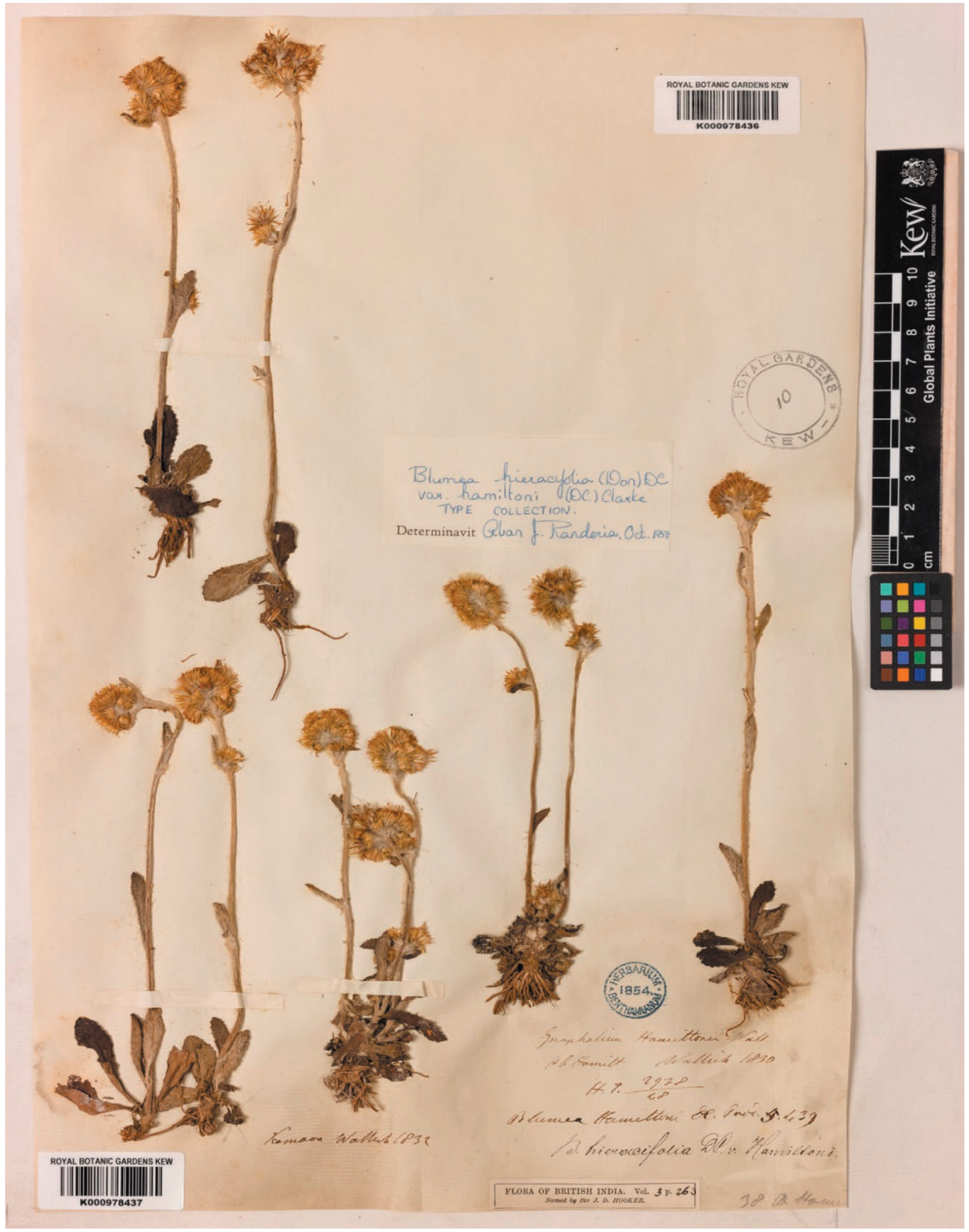

Figure 3. Lectotype of Blumea hamiltonii (K000978436). (C) Copyright of the Board of Trustees of the Royal Botanic Gardens, Kew. 


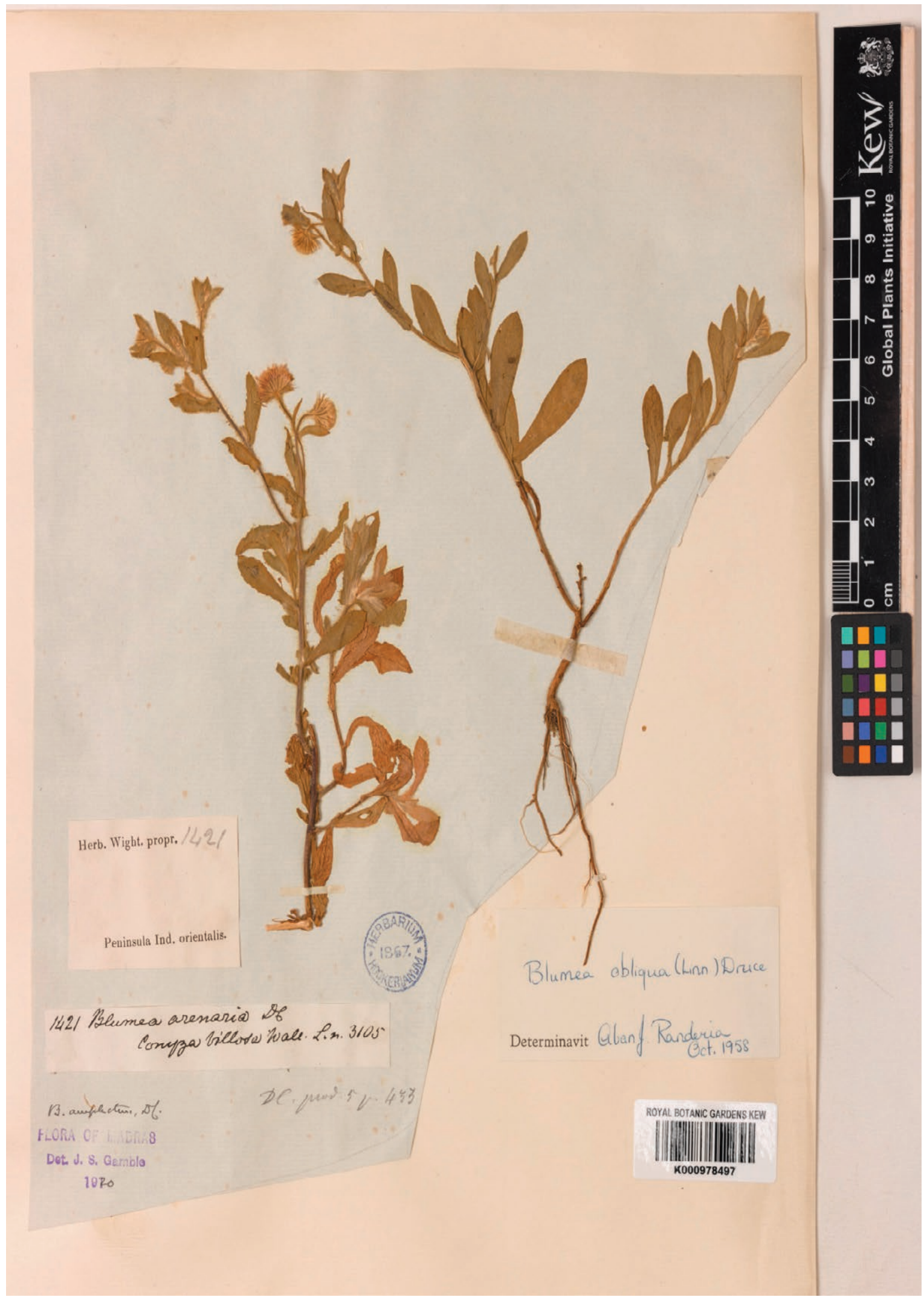

Figure 4. Lectotype of Blumea arenaria (K000978497). ( C Copyright of the Board of Trustees of the Royal Botanic Gardens, Kew. 


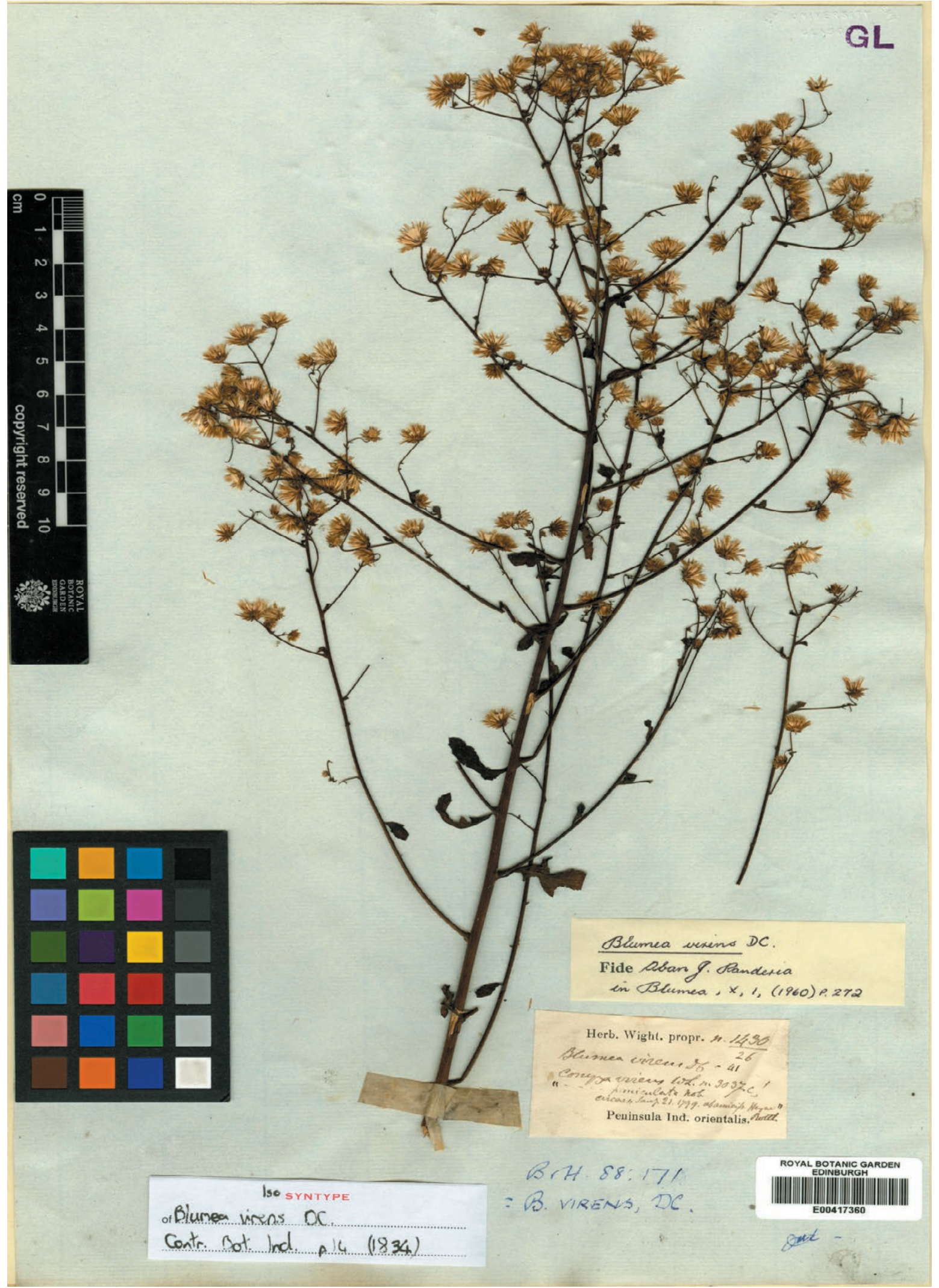

Figure 5. Lectotype of Blumea virens (E00417360). () Copyright of the Board of Trustees of the Royal Botanic Gardens, Kew. 
Blumea cited type specimen as Wight 1430 (E). We traced two sheets from Royal Botanic Garden Edinburgh (E) of Wight's 1430 with different Barcode numbers. Both the sheets have isosyntype labels. One of the sheets has two Blumea virens specimens, but one is a collection of Stocks and Laws. Therefore, Randeria's typification can be treated as effective first step lectotypification (Art. 7.11 of the ICN). In order to narrow the type down to a single specimen second step lectotypification is needed. Therefore the sheet E00417360 is selected here as the second step lectotype. The selected sheet bears a complete and well preserved specimen.

\section{ACKNOWLEDGMENTS}

The authors are thankful to the Board of Trustees of Royal Botanic Gardens, Kew and Royal Botanic Garden, Edinburgh (E) for providing images. Authors are thankful to the authorities of the St. Joseph's College (Autonomous), Devagiri, Kerala for providing facilities. We gratefully thank Dr. A. K. Pradeep, Assistant Professor, Department of Botany, University of Calicut for valuable suggestions. The first author is thankful to Council of Scientific \& Industrial Research (CSIR), New Delhi for Research fellowship.

\section{REFERENCES}

Anderberg AA. 1991. Taxonomy and phylogeny of the tribe Inuleae (Asteraceae). Plant Systematics and Evolution. 176(1-2): 75-123. https://doi.org/10.1007/ BF00937947

De Candolle AP. 1833. Genres nouveaux appartenant à la famille des Composées ou Synanthérées. Archives de Botanique. 2: 514-519.

De Candolle AP. 1836. Compositae. Prodromus Systematis Naturalis Regni Vegetabilis. Vol. 5. Treuttel \& Würtz, Paris.

Giri GS, Mitra B. 1984. On the identity of two varieties of Blumea obliqua (L.) Druce complex. Indian journal of forestry. 7(2): 141-144.

Hajra PK, Rao RR, Singh DK, Uniyal BP. 1995. Flora of India: Asteraceae. Volume 13. Botanical Survey of India; Calcutta.

Hooker JD. 1882. The Flora of British India. Vol. 3. London. Pornpongrungrueng P, Gustafsson $\mathrm{MH}$, Borchsenius F, Koyama H, Chanta ranothai P. 2016. Blumea (Compositae: Inuleae) in continental Southeast Asia. Kew Bulletin. 71(1): 1-46. https://doi.org/10.1007/s12225016-9612-2
Randeria AJ. 1960. The Compositae genus Blumea: A taxonomic revision. Blumea. 10: 176-317.

Turland NJ, Wiersema JH, Barrie FR, Greuter W, Hawksworth DL, Herendeen PS, Knapp S, Kusber WH, Li DZ, Marhold K, May TW, McNeill J, Monro AM, Prado J, Price MJ, Smith GF. 2018. International Code of Nomenclature for algae, fungi, and plants (Shenzhen Code) adopted by the Nineteenth International Botanical Congress Shenzhen, China, July 2017. Regnum Vegetabile. 159. Glashütten: Koeltz Botanical Books. https://doi.org/10.12705/Code.2018

Wallich N. 1829 - 1849. A numerical list of dried specimens of plants in the East India Company Museum, collected under the superintendence of Dr. Wallich of the Company's Botanic Garden at Calcutta. Lithographed manuscript, London.

Wight R. 1834. Contributions to the Botany of India. London. 